\title{
Penerapan Model Dua Tinggal Dua Tamu Dalam Upaya Meningkatkan Aktivitas Dan Hasil Belajar Peserta Didik Kelas II Semester Dua Tahun Pelajaran 2018/2019 Di SD Negeri 40 Ampenan
}

\author{
Hj. Masitah Muluk, S.Pd \\ Guru Kelas II SD Negeri 40 Ampenan
}

\begin{abstract}
Penelitian ini bertujuan untuk mengetahui efektifitas model Duo TT An Competitive Prise dalam upaya meningkatkan aktivitas dan hasil belajar peserta didikKelas IISD Negeri 40 Ampenan. Manfaat penelitian ini adalah mendorong peserta didik untuk mengembangkan ketrampilan belajar dalam kelompok (kognitif) dan bersosiolisasi dengan teman sebagai dalam proses pembelajaran di kelas senyatanya. Dan bagi guru meningkatkan pengembangan pendekatan dan model pembelajaran dengan penerapan saintifik dan strategi discovery learning dalam pembelajaran kerja kelompok (kooperatif) dengan metode diskusi. Penelitian ini dilaksanakan dua siklus, masing-masing siklus kegiatannya adalah; perencanaan, pelaksanaan, observasi dan refleksi. Hasil akhir tindakan pada siklus II menunjukkan bahwa hasil observasi guru sebesar 4,64 hasil observasi peserta didik mencapai skor rata-rata $(4,54)$. Sedangkan perolehan hasil belajar peserta didik mencapai nilai ratarata $(89,69)$, artinya indicator keberhasilan $(\geq 4,0)$ dan hasil belajar $(\geq 75,00)$ telah terlampaui. Karena indicator keberhasilan telah terbukti penelitian dinyatakan berhasil dan dihentikan pada siklus II.
\end{abstract}

Kata Kunci : Aktivitas dan hasil Belajar - Model Duo TT An Competitive Prise.

\section{PENDAHULUAN}

Upaya memandirikan Peserta Didik untuk belajar, bekerjasama, dan menilai diri sendiri diutamakan agar Peserta Didik mampu membangun kemauan, pemahaman, dan pengetahuan. Peningkatan potensi, kecerdasan dan minat Peserta Didik perlu terus di upayakan (Depdiknas, 2004:3). Upaya yang konkrit yang diwujudkan adalah menciptakan pembelajaran yang aktif, kreatif, efektif, dan menyenangkan. Penelitian menunjukkan bahwa lingkungan sosial atau suasana kelas adalah penentu psikologis utama yang mempengaruhi belajar akademis (Walberg dan Greenberg, 1997).

Di SD Negeri 40 Ampenankelas II metode yang sering digunakan oleh hampir semua guru ialah metode ceramah, diskusi, dan tutor sebaya. Sebenarnya metode ini sangat efektif digunakan untuk memancing keaktifan Peserta Didik, namun masih banyak guru yang belum menemukan teknik yang baik untuk menjalankan metode diskusi ini. Selama ini proses diskusi di kelas berlangsung kurang tertib karena jumlah anggota di masing-masing kelompok yakni 68 orang tergolong banyak, hal ini memungkinkan proses diskusi akan didominasi oleh Peserta Didik-Peserta Didik yang memang aktif saja, dan Peserta Didik yang lain cenderung diam. Teknik yang digunakan pun cenderung monoton karena hampir semua guru menggunakan teknik yang sama dalam diskusi kelas. Membentuk kelas menjadi beberapa kelompok, masing-masing kelompok diberikan masalah untuk didiskusikan, kemudian mempresentasikannya di depan kelas dan kelompok yang lain menanggapi kelompok yang presentasi. Hal ini membuat Peserta Didik jenuh dengan metode diskusi yang dilakukan guru, materi pelajaran akan berlalu begitu saja dan penyerapan Peserta Didik terhadap materi kan rendah pula. Karena itu dibutuhkan teknik yang baik dan rapai untuk mengatasi masalah ini. Salah satu teknik yang dapat digunakan untuk menjalankan metode diskusi yaitu teknik Duo TT An Competitive Prise (Dua Tinggal Dua Tamu).

Proses belajar yang baik dilihat dari seberapa aktif peserta didik di kelas ketika proses belajar mengajar berlangsung. Jika tidak ada keaktifanPeserta Didik, sulit akan diharapkan terjadi proses belajar mengajar dalam diri mereka. Dari keaktifan peserta didik ini akan lahirlah harapan-harapan 
terhadap apa yang dipelajarinya. Jika Peserta Didik memiliki harapan yang tinggi, menurut teori dan berbagai penelitian ada kemungkinan untuk berhasil dalam belajarnya. Oleh sebab itu, tugas utama seorang guru dalam melakukan inovasi pembelajaran untuk menghidupkan aktivitas belajar Peserta Didik agar terjadi proses belajar yang optimal.

Berdasarkan permasalahan seperti terpapar di atas, maka dilakukan suatu penelitian dengan judul: "Penerapan Model Dua Tinggal Dua Tamu Dalam Upaya Meningkatkan Aktivitas Dan Hasil Belajar Peserta Didik Kelas II Semester Dua Tahun Pelajaran 2018/2019 Di SD Negeri 40 Ampenan".

\section{Rumusan Masalah}

"Apakah teknik Duo TT An Competitive Prise (Dua Tinggal Dua Tamu) efektif meningkatkan aktivitas dan hasil belajarPeserta Didikkelas IISemester DuaTahun Pelajaran 2018/2019 di SD Negeri 40 Ampenan?"

\section{Tujuan Penelitian}

"Mengetahui efektifitas penerapan model pembelajaran Duo TT An Competitive Prise (Dua Tinggal Dua Tamu)dalam upaya meningkatkan aktivitas dan hasil belajarPeserta Didikkelas IISemester DuaTahun Pelajaran 2018/2019 di SD Negeri 40 Ampenan".

\section{KAJIAN PUSTAKA}

\section{Aktivitas}

Aktivitas belajar peserta didik adalah aktivitas yang bersifat fisik ataupun mental (Sardiman, 2005:96). Aktivitas belajar adalah serangkaian kegiatan fisik atau jasmani maupun mental atau rohani yang saling berkaitan sehingga tercipta belajar yang optimal. Dalam aktivitas belajar ini peserta didik haruslah aktif mendominasi dalam mengikuti proses belajar mengajar sehingga mengembangkan potensi yang ada pada dirinya. Dengan kata lain dalam beraktivitas peserta didik tidak hanya mendengarkan dan mencatat seperti yang dijumpai di sekolahsekolah yang melakukan pembelajaran secara konvensional.

Proses pembelajaran dikatakan efektif bila peserta didik secara aktif ikut terlibat langsung dalam pengorganisasian dan penemuan informasi (pengetahuan), sehingga mereka tidak hanya menerima secara pasif pengetahuan yang diberikan oleh guru. Dalam proses belajar mengajar tugas guru adalah mengembangkan dan menyediakan kondisi agar peserta didik dapat mengembangkan bakat dan potensinya. Menurut Nasution (2000:89, Anonim: 2019), aktivitas belajar adalah aktivitas yang bersifat jasmani ataupun rohani. Dalam proses pembelajaran, kedua aktivitas tersebut harus selalu terkait. Seorang peserta didik akan berpikir selama ia berbuat, tanpa perbuatan maka peserta didik tidak berfikir. Oleh karena itu agar peserta didik aktif berfikir maka peserta didik harus diberi kesempatan untuk berbuat atau beraktivitas.

Hasil belajar tidak hanya ditentukan oleh aktivitas peserta didik tetapi aktivitas guru sangat diperlukan untuk merencanakan kegiatan peserta didik yang bervariasi, sehingga kondisi pembelajaran akan lebih dinamis dan tidak membosankan. Berikut ini jenis aktivitas belajar berdasarkan Depdiknas (2004):

Sebagai indikator aktivitas belajar peserta didik secara individual dalam proses belajar mengajar di kelas adalah sebagai berikut.

1. Kehadiran di kelas

2. Ketepatan waktu mengumpulkan tugas

3. Kelengkapan buku catatan

4. Menyimak dan memperhatikan penjelasan

5. Menyampaikan pendapat

Dalam penelitian ini yang dimaksud dengan aktivitas belajar adalah kegiatan peserta didik mengingat, memecahkan masalah, menganalisis faktor-faktor, melihat hubungan-hubungan, dan membuat keputusan terhadap masalah yang diberikan oleh guru kelas II di SD Negeri 40 Ampenan.

\section{Hasil belajar}

Masalah evaluasi hasil belajar meliputi alat ukur yang digunakan, cara menggunakan, cara penilaian dan evaluasinya (Harus Rasid dan Mansur, 2008:9). Evaluasi hasil belajar yang berhubungan dengan tugas guru rutin dilakukan evaluasi hasil, yang juga dijadikan umpan balik, evaluasi hasil bertujuan menilai apakah hasil belajar dicapai sesuai dengan tujuan (Lukmanul Hakim, 2008:165). 
Pakar pendidikan lain mendefinisikan bahwa yang dimaksud hasil belajar adalah perubahan perilaku secara keseluruhan bukan salah satu aspek potensi kemanusiaan saja (Supriyono, 2009:19). Berbeda dengan pendapatnya Bloom (Dalam Sumiati danAska, 2008). Hasil belajar mencakup kemampuan kognitif, afektif, dan psikomotorik. Jadi pendapat ini mengisyaratkan bahwa haasil belajar peserta didik harus diukur dengan tes tertulis, tes sikap, dan kemampuan skil secara nyata selama proses pembelajaran di kelas senyatanya.

Dalam penelitian ini yang dimaksud dengan hasil belajar adalah tes ulangan harian yang dilaksanakan secara tertulis pada akhir pembelajaran dan nilai hasil diskusi kelompok yang dinilai secara perorangan.

\section{Teknik Duo TT An Competitive Prise}

Teknik belajar mengajar Duo TT (Dua Tinggal Dua Tamu) dikembangkan oleh Spencer Kagen (1992) dan bisa digunakan bersama dengan teknik kepala bernomor. Teknik ini bisa digunakan dalam semua mata pelajaran dan untuk semua tingkatan usia anak didik.

Struktur Dua Tinggal Dua Tamu memberi kesempatan kepada kelompok untuk membagikan hasil dan informasi dengan kelompok lain. Banyak kegiatan belajar mengajar yang diwarnai dengan kegiatankegiatan individu. Peserta Didik bekerja sendiri-sendiri dan tidak diperbolehkan melihat pekerjaan Peserta Didik yang lain. Padahal dalam kenyataan hidup diluar sekolah, kehidupan dan kerja manusia saling bergantung satu dengan yang lainnya. (Anita Lie: 2003;60-61).

Untuk lebih meningkatkan aktivitas dan hasil belajar dalam proses belajar, maka dilakukan permainan-permainan yang melatihPeserta Didik untuk berkompetisi secara sehat. Model Pembelajaran yang digunakan adalah Cooperative Learning dengan teknik Duo TT An Cmpetitive Prise. Teknik ini secara teori dapat digambarkan sebagai berikut:

a. Tujuan

1) memberikan kesempatan kepada kelompok untuk membagikan hasil dan informasi dengan kelompok lainnya sehingga akhirnya Peserta Didik menguasai seluruh indikator yang harus dikuasai.

2) Menumbuhkan motivasi Peserta Didik untuk bersaing dalam berprestasi (achievement motivation)

3) Menanamkan nilai untuk menghargai prestasi dan sportifitas.

b. Cara Penerapannya sebagai berikut:

1) Peserta Didik bekerjasama dalam kelompok berempat untuk mempelajari materi sampai dari sumber-sumber yang relevan dan benar-benar menguasai (ahli dalam bidangnya)

2) Setelah selesai, dua orang dari masingmasing kelompok akan meninggalkan kelompoknya dan masing-masing bertemu kedua kelompok lainnya.

3) Dua orang yang tinggal dalam kelompok bertugas membagikan hasil kerja dan informasi kepada kedua tamunya.

4) Tamu mohon diri dan kembali ke kelompok mereka sendiri dan melaporkan temuan mereka dari kelompok lain.

5) Kelompok mencocokkan dan membahas hasil kerja mereka.

6) Setelah masing-masing kelompok menyelesaikan pekerjaan masing-masing, guru akan memfasilitasi perlombaan antar kelompok, untuk mendapatkan salah satu keluarga terahli dan berhak mendapatkan reward.

7) Pemberian reward sebagai penghargaan dan seluruh Peserta Didik merayakan keberhasilan belajar hari ini.

\section{PROSEDUR PENELITIAN}

\section{Setting Penelitian}

Penelitian tindakan kelas (PTK) ini akan dilaksanakan di kelas IISD Negeri 40 AmpenanSemester DuaTahun Pelajaran 2018/2019, dengan jumlah Peserta Didik sebanyak 27 orang

\section{Faktor yang Diteliti}

1. Faktor Guru: yaitu dengan mengganti cara guru membuat Rencana Pelaksanaan Pembelajaran (RPP) dan pelaksanaannya dalam pembelajaran di kelas senyatanya dengan menerapkan Model Dua TT Competitive Prise (Dua Tinggal Dua Tamu) dalam upaya meningkatkan 
aktivitas dan hasil belajarPeserta DidikKelas IISD Negeri 40 Ampenan.

2. Faktor Peserta Didik: yaitu peningkatan aktivitas dan hasil belajar yang terlihat pada perilaku Peserta Didik selama diskusi kelompok, yang berdampak pada peningkatan aktivitas dan hasil belajarPeserta DidikKelas IISemester DuaTahun Pelajaran 2018/2019 di SD Negeri 40 Ampenan.

\section{Rencana Tindakan}

kegiatan nyata di kelas II yaitu melaksanakan proses pembelajaran dengan menerapkan Model Dua TT An Competitive Prise (Dua Tinggal Dua Tamu) dalam upaya meningkatan aktivitas dan hasil belajarPeserta Didikkelas IISD Negeri 40 AmpenanSemester DuaTahun Pelajaran 2018/2019. Tindakan nyata yang dilakukan oleh guru selaku peneliti adalah dengan menggunakan siklus. Gambaran siklus dalam penelitian ini adalah sebagai berikut:

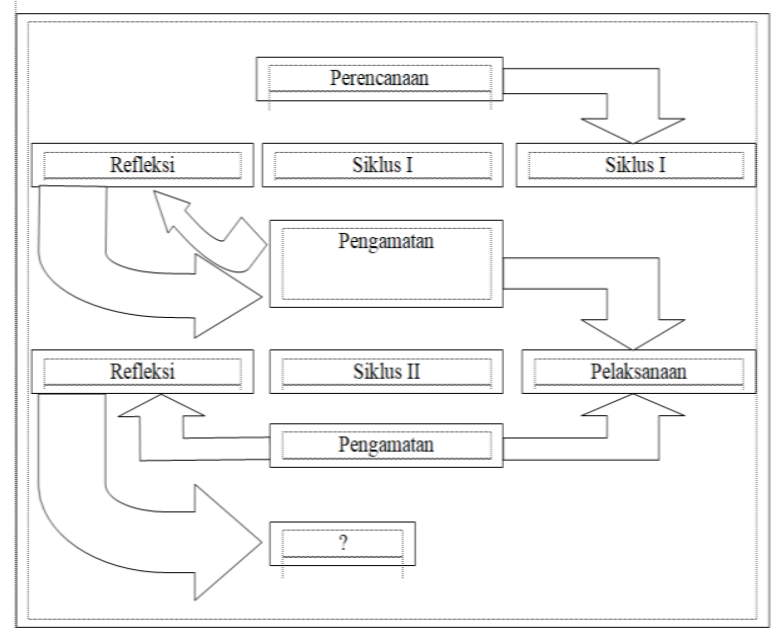

Setiap siklus selama penelitian ini berisi 4 (empat) tahapan yaitu: 1) Perencanaan (Planning), 2) Pelaksanaan (Action), 3) Observasi (Observation), dan 4) Refleksi (Reflection).

\section{Siklus Tindakan}

\section{SIKLUS I}

\section{Tahap Perencanaan (Planning)}

1. Menyusun Rencana Pelaksanaan Pembelajaran (RPP) dengan skenario sesuai dengan aturan main model pembelajaran Dua TT An Competitive Prise (Dua Tinggal Tua Tamu).

2. Menyiapkan sumber, bahan, dan semua alat yang digunakan dalam penelitian.
3. Menyusun/membuat lembar observasi guru dan lembar observasi Peserta Didik.

4. Menyusun alat evaluasi.

Tahap Pelaksanaan (Action)

\section{Pertemuan I}

1. Guru membagi Peserta Didik menjadi 6 (enam) kelompok kecil, masing-masing kelompok beranggotakan 4-5 orang Peserta Didik.

2. Masing-masing kelompok diberikan tugas/soal untuk dipecahkan bersama dalam kelompok, selanjutnya guru berkeliling untuk membimbing kelompok utamanya yang mengalami kesulitan/permasalahan.

\section{Pertemuan II}

3. Masing-masing kelompok 2 orang tinggal ditempat dan 2 orang lagi bertamu ke kelompok yang lain.

4. Tes tertulis

\section{Tahap Observasi (Observation)}

1. Observasi guru :Dilakukan oleh observer sekaligus sebagai pembimbing guru dalam melaksanakan Penelitian Tindakan Kelas (PTK).

2. Observasi Peserta Didik : Dilaksanakan oleh guru mata pelajaran sekaligus sebagai peneliti dalam Penelitian Tindakan Kelas (PTK) pada kegiatan diskusi kelompok. 4).

\section{Tahap Refleksi (Reflection)}

1. Renungan hasil perolehan data

2. Pengolahan dan analisa data hasil penelitian

3. Mencocokkan hasil analisa data dengan indikator keberhasilan

4. Rencana perbaikan dan tindak lanjut

\section{SIKLUS II}

Pada siklus ini semua kegiatan dan tahapan selama penelitian adalah sama, sifatnya mengulang dan memperbaiki terhadap tindakan yang masih memerlukan penyempurnaan dan pembenaran sebagaimana mestinya.

\section{Data dan Cara Pengambilannya. Sumber Data}

Yang menjadi sumber data dalam penelitian tindakan kelas (PTK) ini adalah semua Peserta Didikkelas IISemester DuaTahun Pelajaran 2018/2019 di SD Negeri 40 Ampenan dan peneliti. 


\section{Jenis Data}

- Jenis data yang berasal dari guru selaku peneliti

1). Data tentang Rencana Pelaksanaan Pembelajaran (RPP)

2). Data Pelaksanaan Pembelajaran

- Jenis data yang berasal dari Peserta Didik

1). Data kemajuan aktivitas belajar

2). Data hasil diskusi kelompok/menerima tamu - bertamu

3). Data hasil belajar

\section{Cara Pengambilan data}

- Data kegiatan pembelajaran diambil dari RPP yang dibuat oleh guru dan lembar observasi pelaksanaan model pembelajaran Duo TT An Competitive Prise (Dua Tinggal Dua Tamu)

- Data kemajuan aktivitas belajar; diambil dari lembar observasi selama diskusi kelompok/menerima tamu - bertamu

- Data kemajuan hasil belajar; diambil dari hasil tes tertulis yang dilaksanakan pada akhir proses pembelajaran

Indikator Keberhasilan dan Teknik analisa data

\section{Teknik analisa data}

Untuk menganalisis data akan dilakukan melalui analisis deskriptif kuantitatif melalui pendataan, analisis dan pembahasan terhadap data yang diperoleh dengan mencocokkan tingkat keoptimalan terhadap capaian indikator keberhasilan yang ada.

\section{Indikator Keberhasilan}

1. Guru telah dinyatakan berhasil melaksanakan proses pembelajaran dengan penerapan model Duo TT An Competitive Prise (Dua Tinggal Dua Tamu), bila telah mencapai skor rata-rata $\geq 4,00$ (kategori baik)

2. Aktivitas belajarPeserta Didikkelas II dinyatakan telah meningkat jika $85 \%$ dari jumlah Peserta Didik telah memperoleh skor rata-rata $\geq 4,0$ dan hasil belajar dinyatakan telah meningkat jika $85 \%$ dari jumlah Peserta Didik memperoleh nilai rata-rata $\geq 75,00$ (sesuai KKM).

\section{HASIL PENELITIAN}

DESKRIPSI SIKLUS I

Tahap Perencanaan
Pada tahapan ini yang telah dilakukan oleh guru selaku peneliti adalah; 1) menyusun RPP dengan skenario pembelajaran Duo TT An Competitive Prise, 2) telah berhasil menyiapkan alat, sumber, bahan yang diperlukan dalam penelitian, 3) berhasil menyusun instrument observasi guru dan instrument observasi Peserta Didik, dan 4) menyusun alat evaluasi.

\section{Tahap Pelaksanaan}

1. Guru menyampaikan materi pelajaran dengan pendekatan yang mengacu pada kegiatan Peserta Didik aktif

2. Peserta Didik dibagi menjadi 6 kelompok kecil yang anggotanya 4-5 orang Peserta Didik secara heterogen

3. Peserta Didik berdiskusi dengan anggota kelompoknya untuk memecahkan persoalan/soal-soal yang menjadi tanggung jawabnya.

4. Selama Peserta Didik berdiskusi, guru berkeliling membimbing kelompok sekaligus melakukan observasi/pengamatan terhadap aspekaspek yang telah direncanakan.

5. Masing-masing kelompok dua orang tinggal ditempat untuk menerima tamu dari kelompok lain dan dua orang bertamu kelompok lain.

6. Guru mengamati/mengobservasi ketrampilan Peserta Didik selama proses cara menjawab pertanyaan dari tamu (kelompok lain) dan cara bertanya kepada tuan rumah (bertamu di kelompok lain).

7. Tes tertulis

\section{Tahap Observasi}

Observasi guru memperoleh skor ratarata 3,50, observasi peserta didik memperoleh skor rata-rata pertemuan I $(3,33)$ dan pertemuan II $(3,56)$. Dan perolehan hasil belajar peserta didik dilihat dari nilai tugas dan tes tertulis memperoleh nilai rata-rata sebesar $(64,15)$ dan $(66,89)$

\section{Tahap Refleksi}

1. Renungan data hasil perolehan data pada siklus I

2. Pengolahan data hasil observasi guru, Peserta Didik dan nilai tugas individual dan tes tertulis. 
3. Mencocokkan hasil yang ada dengan Indikator keberhasilan.

4. Merencanakan perbaikan terhadap jenis tindakan yang menyebabkan belum tuntas Indikator keberhasilan. Oleh karena Indikator keberhasilan belum terbukti maka penelitian dilanjutkan ke siklus II.

\section{DESKRIPSI SIKLUS II}

\section{Tahap Perencanaan}

Pada tahapan ini jenis kegiatan yang dilakukan masih mengacu pada kegiatan siklus I, bedanya hanya terjadi perbaikan seperlunya yaitu: 1) penyusunan RPP dengan mengacu pada pendekatan saintifik strategi discovery learning dan diskusi kelompok dan penyempurnaan pada bagian skenario pembelajaran, 2) menyiapkan alat, sumber, bahan yang diperlukan dalam proses tindakan dikelas senyatanyan, 3) menyiapkan lembar observasi guru dan lembar observasi Peserta Didik sebagaimana pada siklus I, 4) menyiapkan alat evaluasi sebagaimana yang telah dibuat pada siklus I.

\section{Tahap Pelaksanaan}

Secara umum tahapan pelaksanaan proses pembelajaran pada siklus II ini masih mengacu pada pelaksanaan proses pembelajaran sebelumnya. Pemecahan yang dilakukan pada proses pembelajaran ini adalah: 1) pelaksanaan proses diskusi kelompok kecil lebih dioptimalkan, 2) pelaksanaan pembimbingan kelompok sekaligus observasi Peserta Didik lebih di efektifkan. Utamanya pengamatan Peserta Didik yang aktif, yang kurang aktif, Peserta Didik yang tidak aktif, dengan harapan proses analisa data lebih signifikan, 3)laporan hasil kerja kelompok yang dibuat secara individu yang dipresentasikan dikelas difokuskan, dan 4) pelaksanaan tes tertulis sebagai perwujudan dari peningkatan hasil belajar Peserta Didiklebih diperketat.

\section{Tahap Observasi}

Observasi guru memperoleh skor ratarata 4,64, observasi peserta didik memperoleh skor rata-rata pertemuan I $(4,48)$ dan pertemuan II $(4,59)$. Dan perolehan hasil belajar peserta didik dilihat dari nilai tugas dan tes tertulis memperoleh nilai rata-rata sebesar $(92,96)$ dan $(86,30)$

\section{Tahap Refleksi}

1. Renungan atas perolehan data hasil observasi guru, observasi Peserta Didik, dan hasil tes tertulis sebagai wujud dari peningkatan aktivitas dan hasil belajarPeserta Didik di kelas senyatanya.

2. Pengolahan data hasil observasi guru, observasi Peserta Didik, presentasi Peserta Didik dan tes tertulis

3. Mencocokkan perolehan data hasil tindakan dengan Indikator keberhasilan yang telah ditetapkan.

4. Guru memberikan hadiah/reward kepada semua Peserta Didikkelas II atas keberhasilannya dalam upaya meningkatkan aktivitas belajar yang berdampak terhadap perolehan hasil belajar sesuai dengan KKM yang telah ditetapkan.

\section{PEMBAHASAN \\ SIKLUS I}

\section{Tahap Perencanaan}

Peneliti telah menyusun RPP dengan skenario penerapan Model Duo TT An Competitive Prise, menyiapkan alat, sumber, bahan yang diperlukan dalam proses pembelajaran, menyusun instrument observasi guru maupun instrument observasi siswa, mengalami beberapa kendala. Tetapi setelah berkonsultasi dan meminta petunjuk kepada pembimbing, akhirnya kendala pundapat diatasi dengan baik.

\section{Tahap Pelaksanaan}

\section{a. Tahap 1}

- Guru menugaskan kepada Peserta Didik secara berkelompok untuk menggali informasi dari buku paket tentang materi pelajaran yang disajikan.

- Guru menjelaskan materi pelajaran dan memberikan contoh konkrit yang bisa dimengerti oleh Peserta Didik

b. Tahap 2

- Guru memberikan trik-trik kepada Peserta Didik tentang tata cara bertanya yang baik dan benar sesuai dengan materi pelajaran yang sedang disajikan.

- Peserta Didik secara teratur bertanya tentang hal-hal yang belum dimengerti sesuai materi yang sedang dipelajari.

c. Tahap 3 
- Secara berkelompok Peserta Didik mendiskusikan masalah yang menjadi tanggung jawabnya.

- Melakukan eksperimen dalam kelompok terhaadap permasalahan yang sedang di diskusikan

- Mengumpulkan data yang berasal dari semua anggota kelompok

d. Tahap 4

- Semua anggota kelompok dibagi menjadi 2 (dua) kegiatan, 2 orang tinggal ditempat dan 2 orang bertamu

- Tugas 2 orang yang tinggal di tempat menerima tamu dan memberikan penjelasan tentang soal yang menjadi tanggung jawabnya

- tugas dua orang yang bertamu menanyakan hasil kerja kelompok lain samai kelompok semua kelompok dikunjungi.

e. Tahap 5

- Guru mempersilahkan kepada semua anggota kelompok untuk menginformaasikan hasil kerja kelompoknya.

- Peserta Didik dengan bimbingan guru membuat kesimpulan bersama dari seluruh permasalahan/soal yang menjadi tanggung jawabnya.

- Tes tertulis.

\section{Tahap Observasi}

Observasi guru memperoleh skor ratarata $(3,50)$, Hasil observasi Peserta Didik dalam upaya peningkatan aktivitas dan hasil belajarPeserta Didikkelas IISemester DuaTahun Pelajaran 2018/2019 di SD Negeri 40 Ampenan diperoleh skor rata-rata tahap I $(3,33)$ dan tahap II $(3,56)$. Dari hasil tes tertulis yang materinya hanya sekitar yang diajarkan pada saat itu juga, diperoleh nilai rata-rata $(65,52)$ kategori cukup.

\section{Tahap Refleksi}

Hasil analisa data peningkatan aktivitas belajar pada siklus I ini $(3,33)$ dan bertamumenerima tamu $(3,56)$, sedangkan yang diminta dalam Indikator keberhasilan $(\geq 4,0)$, ini artinya belum berhasil.

Karena Indikator keberhasilan belum tercapai, penelitian tindakan kelas (PTK) dilanjutkan ke siklus II dengan harapan optimalisasi penerapan strategi pembelajaran dengan Model Dua TT An Competitive Prise (Dua Tinggal Dua Tamu) dapat meningkatkan aktivitas dan hasil belajarPeserta Didikkelas IISemester DuaTahun Pelajaran 2018/2019 di SD Negeri 40 Ampenan.

\section{SIKLUS II}

\section{Tahap Perencanaan}

Peneliti menyusun Rencana

Pelaksanaan Pembelajaran (RPP) dengan memperhatikan kesalahan-kesalahan pada siklus I. peneliti lebih memfokuskan tentang Rencana strategi jitu sehingga proses pembelajaran dengan Model Dua TT An Competitive Prise (Dua Tinggal Dua Tamu) dapat terelaisasi dengan baik, karenanya dalam penyusunan skenario benar-benar dirinci dari tiap aspek pada proses pembelajaran.

Sebelum proses pembelajaran dilaksanakan, peneliti menyiapkan semua alat, bahan, dan segala sesuatunya sehingga dalam pelaksanaan proses pembelajaran berjalan sesuai dengan skenario yang telah direncanakan. Agar proses pembelajaran dapat teratasi maka peneliti juga menyiapkan lembar observasi guru dan lembar observasi Peserta Didik sebagai tolak ukur ketercapaian peningkatan aktivitas dan hasil belajarPeserta Didikkelas IISD Negeri 40 Ampenan.

\section{Tahap Pelaksanaan}

Pada tahap pelaksanaan di siklus II ini pada dasarnya masih mengacu pada pelaksanaan siklus I, yaitu penerapan pendekatan Model Duo TT An Competitive Prise. Bedanya pada siklus ini lebih dioptimalkan.

\section{Tahap Observasi}

Pada siklus II ini hasil observasi guru memperoleh skor rata-rata $(4,64)$, Upaya meningkatkan aktivitas belajarPeserta Didikkelas IISemester DuaTahun Pelajaran 2018/2019 di SD Negeri 40 Ampenan pada tahap I diperoleh skor rata-rata $(4,48)$ dan tahap II (4,59), dampak nyata dari meningkatnya aktivitas belajar adalah hasil belajar juga meningkat, dari data hasil perolehan nilai rata-rata tugas $(92,96)$ dan tes tertulis adalah $(86,30)$ berarti mengalami peningkatan yang sangat signifikan.

\section{Tahap Refleksi}


Hasil analisa data peningkatan aktivitas dan hasil belajarPeserta Didik pada siklus II adalah $(4,48)$ dan $(4,59)$ serta $(89,63)$ sedangkan Indikator keberhasilan $(\geq 4,0)$ dan $\geq 75,00$. Ini artinya pada siklus II hasilnya telah melampaui Indikator keberhasilan yang telah di tetapkan.

Karena Indikator keberhasilan telah terbukti, maka tidak perlu ada upaya perbaikan dan penyempurnaan. Model Dua TT An Competitive Prise (Dua Tinggal Dua Tamu) telah mampu meningkatkan aktivitas dan hasil belajarPeserta Didik yang ditandai dengan tercapainya Indikator keberhasilan dan terjadinya peningkatan hasil belajar Peserta Didik. "Penelitian Tindakan Kelas (PTK) dihentikan pada siklus II dengan hasil memuaskan."

\section{SIMPULAN}

Data komulatif dari hasil penelitian tindakan kelas (PTK) dari siklus I ke Siklus II adalah sebagai berikut:

\begin{tabular}{|l|l|c|c|c|c|}
\hline No & \multicolumn{1}{|c|}{ Jenis Kegiatan } & $\begin{array}{c}\text { Indikator } \\
\text { keberhasilan }\end{array}$ & Siklus I & Siklus II & Keterangan \\
\hline 1. & Observasi Guru & $\geq 4,00$ & 3,50 & 4,64 & Meningkat \\
\hline 2. & Observasi Peserta Didik & $\geq 4,00$ & 3,33 & 4,48 & Meningkat \\
\hline 3. & Bertamu - Menerima Tamu & $\geq 4,00$ & 3,56 & 4,59 & Meningkat \\
\hline 4. & Tugas & $\geq 75,00$ & 64,15 & 92,96 & Meningkat \\
\hline 5. & Tes tertulis & $\geq 75,00$ & 66,89 & 86,30 & Meningkat \\
\hline
\end{tabular}

Penerapan Model Dua TT An Competitive Prise (Dua Tinggal Dua Tamu) sangat efektif upaya untuk meningkatkan aktivitas dan hasil belajarPeserta Didikkelas IISemester DuaTahun Pelajaran 2018/2019 di SD Negeri 40 Ampenan. Fakta telah menunjukkan perolehan rata-rata skor aktivitas belajarPeserta Didik pada siklus I ke siklus II sudah melampaui Indikator keberhasilan yang ditetapkan. Penelitian dinyatakan "berhasil" dan dihentikan pada siklus II.

\section{SARAN}

Disarankan kepada guru sejawat untuk melaksanakan Penelitian Tindakan Kelas (PTK) dalam upaya untuk meningkatkan aktivitas dan hasil belajarPeserta Didik sesuai dengan mata pelajaran masing-masing.
Disarankan kepada para semua Peserta Didikkelas IISD Negeri 40 Ampenan untuk membiasakan belajar dengan pendekatan yang kontekstual utamanya strategi yang mampu membangkitkan aktivitas belajarPeserta Didik yang dampaknya hasil belajar dapat ditingkatkan seperti yang diharapkan

\section{DAFTAR PUSTAKA}

Anonim 2019 , dalam http://dadangjsn.blogspot.com/2016/0 6/pengertiandefinisi-pendekatansaintifik.html, diambil tanggal 8 Januari 2019, Pukul 20.35 Wita

Anonim, 2019, dalam https://www.eurekapendidikan.com/20 15/10/definisi-aktivitas-belajar.html, diambil tanggal 8 Januari 2019, Pukul 20.35 Wita

Arikunto, s. 2009, Penelitian Tindakan Kelas, Jakarta : Bumi Aksara.

Harun Rasyid dan Mansur, 2008, Penilaian Hasil Belajar, Bandung : CV Wacana Prima.

Lukmanul A, 2008, Perencanaan Pembelajaran, Bandung : CV Wacana Prima.

Mukhtar, 2003, Prosedur Penilaian, Jakarta : Rineka Cipta.

Nurhadi, 2003, Yasin ,B dan Sendule.A, 2003, Kontekstual dan Penerapannya dalam KBK, Malang : Unitipetas Negeri Malang.

Nurhayati. 2006. Upaya Meningkatkan Aktivitas dan hasil belajarPeserta Didik Mata Pelajaran IPA Melalui Metode CIRC. Jakarta: Depdiknas

Robert E Slavin, 2010, Cooperative Learning Teori, riset dan Praktik, Bandung : Nusa Media.

Sardiman, 2007, Indikator Dan Aktivitas belajar Mengajar, Jakarta : Raja Grafindo Perkasa.

Supriono, 2009, Cooperative Learning Teori dan Aplikasi PAIKEM, Yogyakarta : Pustaka Pelajar.

Syahrir, S., \& Susilawati, S. (2015). Pengembangan Modul Pembelajaran Matematika Siswa SMP. Jurnal Ilmiah Mandala Education (JIME), 1(2), 162171. 
Syamsudin, M. 2002. Psikologi Pendidikan.

Bandung: Remaja Rosdakarya

Permen 81A Tahun 2013 Tentang

Implementasi Kurikulum 2013

Permen 103 Tahun 2014 Tentang Standar Proses 